\title{
JOSEF STEPLING A ROYAL SOCIETY JEŠTĚ JEDNOU
}

\author{
JOSEF SMOLKA
}

\section{JOSEF STEPLING AND THE ROYAL SOCIETY ONCE AGAIN}

This contribution offers an analysis and edition of the Latin original and Czech translation of already the second letter sent by Josef Stepling to James Short. The letters were found in the Archives of the Royal Society in London. The first dealt with the fall of meteorites in southern Bohemia, the second (subject of the current study) describes how the impact of Lisbon earthquake that took place on 1 November 1755 was felt in the west Bohemian spa town of Teplice. The author also traces Stepling's later interest in this natural phenomenon.

Keywords: Josef Stepling - James Short - Royal Society London - earthquake - Lisbon - 18th century - physics - natural sciences

DOI: $10.14712 / 23365730.2019 .20$

\section{Věnováno Dr. P. Kroupovi}

Není tomu dlouho, co jsme mohli uveřejnit studii věnovanou dopisu Josefa Steplinga Jamesu Shortovi, členu v té době nejprestižnější vědecké instituce Royal Society. ${ }^{1} \mathrm{~V}$ jeho korespondenci, kterou dosud známe prakticky jen z její tištěné podoby, ${ }^{2}$ představuje tento dopis druhý autograf. ${ }^{3}$ Jeho hlavní část pojednávala o neobyčejném prrírodním úkazu, o hromadném pádu kamenů - meteoritů -, k němuž došlo 3. července 1753 poblíž obce Strkov u jihočeského Tábora. Brzy poté se ukázalo, že archiv Royal Society uchovává ještě jeden Steplingův list - bohužel ne více. ${ }^{4}$ Ten je z ledna 1756 a referuje opět o naprosto mimořádném přírodním jevu, o změnách, $\mathrm{k}$ nimž došlo 1 . listopadu 1755 na hlavním termálním pramenu lázní Teplice v Čechách. Zatímco zprávu v prvém listu si londýnský astronom u Steplinga zřejmě vyžádal, zdá se, že tentokráte jej - a v jeho osobě i celou Royal Society - informoval náš osvícenský vědec z vlastního popudu. Vzhledem k tomu, že se jedná o dopis neobyčejně závažného obsahu, dovolujeme si otisknout jeho text in extenso, a to v latinském originálu i v našem českém překladu.

Srov. Josef Smolka, Josef Stepling v archivu Royal Society, Dějiny věd a techniky 49/3, 2016, s. $194-206$.

2 Clarissimi ac magnifici viri Josephi Stepling ... litterarum commercium eruditi cum primis argumenti, Wratislaviae 1782.

3 Prvý autograf uložený v tzv. Boškovičově archivu v knihovně Kalifornské university jsme uveřejnili již před delší dobou, srov. Josef Smolka, Neznámý Steplingův dopis Boškovičovi, Dějiny věd a techniky 2, 1970, s. $240-241$.

4 Za tuto informaci patří náš dík archivářce Royal Society paní Katherine Marshall. S tímto nálezem čtenáře stručně seznámil příspěvek: Jana VACKÁŘová - Josef SmolkA, Josef Stepling a lisabonské zemětřesení roku 1755 , Dějiny a současnost 41/1, 2019, s. 22-23. 


\section{Stepling Jamesi Shortovi}

Praha, 30. ledna 1756

Archiv Royal Society, rkp. č. L\&P/III/115/1-4

(fol. 1)

Clarissime Vir,

Töplitzio (quod est vicus thermis salutatibus insignis 9 milliaribus Bohemicis Praga dissitus versus $N W$ fere) rumor allatus est mutationem aliquam subivisse scaturiginem thermarum principem. Quare volens certi aliquid referre, rogavi Supremi Consilii Regii (Repraesentationem vocant) Praesidem, uti is adcuratam vi relationem iuxta puncta a me proposita ad se referri juberet. Hac via relationem obtinui sequentem.

Anno 762 detectas esse, ac repertas has thermas et ab illo tempore scaturiginem prima(fol. 2) riam perpetuo eadem quantitate, et qualitate aquas calidas profudisse. 2 do. Prima Novembris anni superioris 175511 inter, ac 12 mam matutinam scaturiginem primariam tantam vim aquarum dedisse, ut spatio horae dimiduae omnia balnea inundata fuerint. 3 tio. Hora circiter dimidia ante insigne hoc aquae incrementum scaturiginem turbatam fuisse, ac lubulentam fluxisse, tandem vero cessasse penitus, per unum fere minutum horarium, mox ingenti impetu prorupisse, ac ante se propulisse copiam croci mortialis ?? (fol. 3) deinceps clariorem redditam esse ita, ut tam pura, ac alias fluxerit. 4to. Fluere ad hoc usque tempus tam puram uti alias, sed plus aquae, ac calidiorem, vique medica intensiore proditam dare.

Vides, Vir Clarissime, mutationem huius scaturiginis eo fieri tempore, quo Lusitania terrae motibus concuti coepta. Quare, cum non dubitem de variis locis relationis de terrae motu tam diffuso datas ad Illustrissimam Reg.[iam] Societatem, hanc etiam non ingratam fore putavi.

Vale, ac fave, Cla.[rissime] ac Celeberrime Vir

Pragae 30. Jan.[uarii] 1756

(fol. 4)

A Mr.

Mr. James Schort

de la Société Royale de Londres

Em Surrey Street dans le Strand

par Flandres

a Londres

\section{Český překlad}

(fol. 1)

Nejjasnější Pane,

z Teplic (což je vesnice vyznačující se léčivými prameny ležící 9 českých mil ${ }^{5}$ od Prahy téměř severozápadním směrem ${ }^{6}$ ) se donesla zvěst, že došlo k nějaké změně na hlavním

5 Jedna česká míle odpovídá 7530 metrům - 9 mil by tedy činilo necelých $68 \mathrm{~km}$. Dnešní údaje o vzdálenosti mezi Prahou a Teplicemi se pohybují kolem $89 \mathrm{~km}$. Znamená to, že Steplingův údaj je hodně podhodnocen.

6 Teplice leží od Prahy spíše na severo-severozápad. Ani zde není tedy Stepling př́iliš přesný. Taková byla ovšem tehdejší topografie a kartografie. 
lázeňském zřídle. Protože jsem se chtěl dozvědět něco jistého, požádal jsem předsedu nejvyšší královské rady (nazývá se representací7), aby přikázal vypracovat přesnou zprávu podle bodů, které jsem navrhl. Touto cestou jsem obdržel následující zprávu.

Tyto teplé prameny byly objeveny a nalezeny v roce $762^{8} \mathrm{a}$ od této doby z hlavního pramene (fol. 2) neustále tryskají v tomtéž množství i kvalitě teplé vody. Zadruhé: 1. listopadu predchozího roku 1755, mezi 11. a 12. hodinou dopolední, dávalo hlavní zř́́dlo takovou sílu vod, že za půl hodiny byly celé lázně zatopeny. Zatřetí: asi půl hodiny před tímto význačným nárůstem vody se zř́íllo rozbouřilo a volně tryskalo, nakonec však úplně přestalo, téměř na jednu minutu, ${ }^{9}$ brzy poté vyrazilo mohutným proudem a hnalo před sebou množství železitého šafránu. ${ }^{10}$ (fol. 3) Začtvrté: poté tekla voda čistá jako předtím, ${ }^{11}$ ale pramen dával více vody, a teplejší a s intensivnější léčebnou silou. ${ }^{12}$

Vidíš, nejjasnější pane, že změna tohoto zřídla se udála v té době, kdy se Portugalsko začalo otřásat zemětřesením. A protože nepochybuji o tom, že tak rozsáhlé zemětřesení se vztahuje na různá místa, domníval jsem se, že tuto zprávu uvítá i přeslavná Královská společnost.

Bud' zdráv a měj se dobře, nejjasnější a přeslavný pane

V Praze 30. ledna 1756

(fol. 4)

Panu

panu Jamesi Schortovi

z Královské společnosti v Londýně

ul. Surrey u ul. Strand

přes Flandry do Londýna

7 Tzv. královská representace byla v letech 1749-1763 v Čechách nejvyšším zemským správním orgánem.

8 Tento údaj pochází od Hájka z Libočan. Tehdejší lázeňský lékař Heinrich Gottlob Nepomuk TroschEL, Allgemeine Bemerkungen über die Teplitzer Wasser zur nöthigen Nachricht der Cur-Gäste, Greitz 1761, s. A 5/3, však uvádí řadu dalších dat: podle Balbína to bylo nap̌r. údajně r. 566, podle Codicilla a Veleslavína dokonce už r. 462. Archeologické nálezy však naznačují, že zdejší teplé zřídlo znali už i Keltové před naším letopočtem. Prvý písemný záznam o něm pochází však až z r. 1057.

9 Troschelův spis, citovaný v předchozí poznámce, líčí na s. B 2/2 tento výpadek jinak: „... blieb auf einmal der Sprung der Quelle durch sechs bis sieben Minuten völlig aus.“ Zde i v dalším jde o versi, kterou převzal Troschel od svého nejmenovaného předchůdce ve funkci lázeňského lékaře.

$10 \mathrm{~V}$ anglickém překladu, který pořídila Royal Society - otiskujeme jej níže - jsou zde přidána slůvka ,reddish oker“, okrově žlutý, načervenalý. Nejde ale samozřejmě o šafrán, ale o železitý oxyd, ferrum oxydulatum nigrum, Eisensafran. Tak označuje tuto látku Ernst Friedrich ANTON, Handwörterbuch der chemisch-pharmazeutischen Nomenklaturen, oder Uebersicht aller lateinischen, deutschen und französischen Benennungen..., Nürnberg 1833, s. 80.

11 I zde se Troschelův popis liší: „Die Farbe dieses Wassers war blutroth und blieb in dieser Beschaffenheit eine halbe Stunde." Tamtéž, s. B 2/2.

12 Zde se oba popisy shodují. Troschel jen pochybuje o tom, že by zvýšení teploty pramene mohlo dosáhnout tří stupňů. 
List je pro Steplinga a jeho odbornou seriosnost charakteristický. V případě pádu strkovských kamenů - dříve než o nich vydal svůj spisek ${ }^{13}$ - si vyžádal ověření a doplnění svých informací od táborského děkana Josefa Klášterského. Podobně i tentokrát si zprávu, se kterou se seznámil jen z doslechu, nechal ověřit od našeho nejvyššího správního orgánu. V předcházejících poznámkách jsme však mohli ukázat, že ve vzpomínkách lázeňského lékaře, Troschelova zemřelého předchůdce, proběhla událost trochu jinak - to však Stepling v době, kdy psal Shortovi, nemohl znát, nebot' Troschelův spis vyšel o pět let později. Které z těchto dvou líčení je autentičtější, už dnes asi nelze rozhodnout.

Popsání změn na teplickém pramenu, které Stepling zaslal do Londýna, je však stručné a jasné. Věcné a lakonické je také jeho konstatování, že změny vyvolalo rozsáhlé zemětřesení, které vzniklo 1. listopadu 1755 a postihlo zejména portugalský Lisabon. Dosáhlo 9. magnitudy a až dodnes patři $\mathrm{k}$ největším prrírodním katastrofám, k nimž v evropských dějinách došlo. Údaje o ztrátách na lidských životech se hodně různí, některé odhady uvádějí až 60000 osob z tehdejších 250000 obyvatel Lisabonu. Údajně se tu zrrítilo na 9000 budov. ${ }^{14}$

Logika Steplingova uvažování je jednoznačná, vychází z dokonalé časové shody počátku obou událostí, které spadají do dopoledních hodin zmíněného 1. listopadu 1755. Ačkoli nebyl vzdělán v geologii - ta se jako věda zatím ještě nekonstituovala -, není Stepling ani v nejmenším udiven obrovskou vzdáleností obou lokalit, která činí kolem 2500 km. Chápal evropský kontinent zřejmě jako jednotný geologický útvar. Jeho slova jsou také prosta jakýchkoli moralit o trestu božím apod., kterých se - jako obvykle po takovýchto tragédiích - vynořila celá řada. ${ }^{15}$ Ačkoli byl jako jezuitský profesor filosofie zároveň i doktorem teologie, zaujal Stepling v této záležitosti naprosto striktní př́rodovědecký postoj.

V předchozí studii jsme mohli ukázat, že Steplingův dopis o změnách na teplickém prameni se četl v překladu do angličtiny na zasedání Royal Society, a to 26. února 1756. ${ }^{16}$ Na pořadu bylo tehdy mj. jedenáct zpráv „,cizinců“, tj. nečlenů společnosti. Jako prvá byla čtena jakási starší zpráva týkající se logaritmů, ale hned po ní druhý, novější list Steplingův z 30. ledna 1756. Asi proto, že se týkal portugalského zemětřesení, které vyvolalo po celé Evropě velký ohlas, bylo tedy aktuální a referovalo se už o něm na předchozích zasedáních. Jako poslední se pak četl prvý, starší Steplingův list o pádu strkovských kamenů. M. Grossman naznačuje, že toto téma nevzbudilo př́lišs velký zájem: jednak to bylo už na konci zasedání, jednak šlo také o událost starou už tři roky. Snad i proto nebyl text Steplingova prvého listu otištěn ve Philosophical Transactions, což byl jinak běžný postup. Snažili jsme se proto najít v tomto londýnském časopise alespoň přetisk Steplingtova druhého,

13 Josef Stepling, De pluvia lapidea anni MDCCLIII ad Strkov pagum uno milliari Taborio Bohemiae urbe dissitum, et ejus causis meditatio,... lecta in consessu philosophico mense Augusto anno eodem et approbata, Pragae 1754.

14 O této události, která se stala jedním z podnětů ke vzniku nového vědeckého odvětví - seismiky - existuje poměrně bohatá literatura. Velkou část ji lze najít v rozsáhlém sborníku Gerhard LAUER - Thorsten UNGER (Hgg.), Das Erdbeben von Lissabon und der Katastrophendiskurs im 18. Jahrhundert, Göttingen 2008.

15 Nevyhnuli se jim ani někteří vzdělaní vědci. Z mnoha dalších jmenujme např. spis profesora helmstedtské university a lékaře: Johann Gottlob KRÜGER, Gedancken von den Ursachen des Erdbebens nebst einer moralischen Betrachtung, Halle 1756.

16 Průběh zasedání podrobně popsal Mark Grossman, Joseph Stepling and the Tabor Meteorite Fall, in: Meteorite. The International Quarterly of Meteorites and Meteorite Science 17(2), May 2011, s. 15. 
pozdějšího listu. Čekalo nás však nemilé překvapení: pražské Klementinum, Strahov ani Národní museum ve svých fondech tento časopis nemají. Je tedy sporné, zda tehdy do Čech vůbec docházel. Zato jsme však zjistili, že v pražské Národní knihovně (sign. 38 D 5) existuje přetisk Philosophical Transactions vydávaný s odstupem téměř dvou desetiletí v německém Wittenberku. To je skutečnost velmi málo známá. V př́islušném svazku ${ }^{17}$ tohoto vydání najdeme i Steplingův dopis. Je přeložen do angličtiny, členové Royal Society v této době už latinu definitivně opustili. Jeho text s marginální poznámkou „Read Feb. 26, 1756 " zní takto:

Letter XXXV - An Account of the extraordinary Alteration in the Bath of Töplitz, in Bohemia, on the first of November 1755, in a letter from Father Steplin to James Short, M.A.F.R.S. translated from the Latin.

$S I R$,

A Report beeing brought hither, that in Toplitz, a village famous for its baths, and nine Bohemian miles north-west from Prague, the source of these baths had undergone some change; in order to know the truth of this, I requested the President of the Supreme Royal Council to send me an exact account of it, in answer to the several questions, whitch I proposed to him. By this means I have procured the following relation of that fact: That in the year 762 those bath were discovered; from which time the principal spring of themhad constantly thrown out the hot waters in the same quantity, and of the same quality. On the first of November of the last year 1755, between eleven and twelve in the morning, the chief spring cast up forth such a quantity of water, that in the space of half an hour all the bath ran over. About half an hour before this vast increase of the water the spring grew turbid, and flowed muddy; and, having flopped intirely near a minute, broke forth again with prodigious violence, driving before it a considerable quantity of a reddish oker, Crocus Martialis. After which it became clear, and flow'd as pure as before; and continues still to do so; but it supplies more water than usual, and that hotter, and more impregnated with its medicinal quality.

You see, Sir, that the alteration made in this spring happened almost at the very time when Portugal began to be shook with the earthquake. Not doubting therefore, that accounts from various parts concerning the effects of so extensive an earthquake will be sent to the Royal Society, I presum'd, that this would not prove unacceptable to them. I am

$S I R$,

your most humble servant J. Steplin

Překlad Steplingova listu je poměrně velmi přesný, vynechány jsou jen číslovky, jimiž Stepling rozdělil své sdělení na čtyři části. Zaujme nás však forma Steplingova příjmení, která zde zní „Steplin“, tedy bez koncového „g“. Není to ale tisková chyba, v této formě se totiž vyskytuje i v nepaginovaném rejstř́ku této knihy. ${ }^{18} \mathrm{~S}$ takovouto odchylkou se nese-

17 Philosophical Transactions, giving some Account of the Present Undertakings, Studies and Labours of the Ingenious in many Considerable Parts of the World. Reprinted according to the London Edition, Wittenberg 1770, Vol. YLIX, Part I. for the Year 1755, s. 192-193.

18 Zápis v rejstříku zní „Steplin (Father Joseph), his Account of the extraordinary Alteration in the Bath of Töplitz...“. 
tkáváme poprvé: najdeme ji i v matričním zápisu z chrámu sv. Ulricha v Řezně. Takto je S ní zapsán nejen Josef (Josef František Stepling), ale i jeho o rok starší sestra Josefka. ${ }^{19}$ Musíme se však domnívat, že souběh těchto skutečností je jen zcela náhodný a že spolu vzájemně nikterak nesouvisejí. Forma „Steplin“ v anglickém překladu je zvláštní, v latinském originálu Steplingova listu je koncové ,g“ totiž naprosto zřetelně čitelné.

Vrat'me se však ke čtení Steplingova dopisu před londýnskými akademiky. Jeho zkrácený obsah byl zapsán do jakéhosi deníku společnosti vedeného od r. 1660 a zvaného Journal Book of the Royal Society of London (1754-1757, XXIII, s. 289-290). ${ }^{20}$ To všechno má pro nás nesmírný význam, byla to jedna z mála příležitostí, kdy se problematika týkající se našich zemí dostala do zorného úhlu této, $v$ dané době snad vůbec nejvýznamnější vědecké společnosti.

O lisabonské zemětřesení se zajímal Stepling i v př́ištích týdnech. Hned 5. prosince 1755 adresuje francouzskému fysikovi Antoinu Nolletovi dotaz na jeho účinky ve Francii. ${ }^{21}$ Podobně se obrátil na svého př́itele z Würzburgu, Franze Hubertiho, a to v listě, který se ale nezachoval. Známe však Hubertiho odpověd' z 28. prosince téhož roku - vyjmenoval Steplingovi řadu míst, kam všude zemětřesení dorazilo. ${ }^{22}$

I v příštím roce 1756 zůstávala problematika zemětřesení na pražské filosofické fakultě stále živá. Někdy počátkem roku zde vychází rozprava o zemětřesení, ${ }^{23}$ na jejím titulním listě však není vyznačen autor. Čornejová a Fechtnerová přisuzují autorství Steplingovu žákovi Kašparu Sagnerovi (1721-1781), ${ }^{24}$ podobně autorský katalog pražské Národní knihovny a dlouho před nimi i Wurzbachův slovník. ${ }^{25}$ Rozpravu cituje i Zíbrt, který uvádí jako autora Fel. Köhlera, ${ }^{26}$ to je však kardinální omyl: to byl jeden ze studentů, kteř́ tento text obhajovali. Prameny 18. století připisují toto pojednání jednoznačně Steplingovi. ${ }^{27}$ Jako nepřímý důkaz může snad posloužit i skutečnost, že žádná další literární informace o Sagnerovi jej jako autora tohoto spisku neuvádí. ${ }^{28}$ Podstatné přitom ale je, že ani jedna strana se nezmiňuje o tom, oč svůj názor opírají.

19 Blíže o tom Josef Smolka, K pưvodu Josefa Steplinga, Dějiny věd a techniky 46, 2013, s. 151-163, zde s. 155.

20 Srov. M. Grossmann, Handwritten Letter, Meteorite, January 11, 2011, s. 8, a TÝž, Final thoughts, tamtéž, January 14, 2011, s. 6. Dodejme ještě, že počátkem 19. století se v Anglii objevila zpráva o teplické události znovu, a to v knize, která přebírala svůj obsah z Philosophical Transactions, srov. C. C. Clarke, Natural Philosophy or, A Popular Display of the Wonders of Nature, London 1828, s. 368.

21 „De nupero insigni terrae motu quid Tibi videtur? an in Galliis quoque perlata est? ... si apud vos, quod facilius est, certiora de adiunctis physicis phaenomeni ex Portugalia perlata sunt, oro." Viz Litterarum commercium eruditi cum primis argumenti, Vratislaviae 1782, s. 393.

22 „Terrae motus plura circa nos pervasit ...", napsal Huberti a poté vyjmenoval deset lokalit středního a jižního Německa. Tamtéž, s. 440-441.

23 Discursus de terrae motus causa, occasione similium anni superioris, et labentis MDCCLVI XXX. Martii in conventu literario philosophico lectus, Pragae s. d. /1756/.

24 Ivana ČORnEJOvÁ - Anna FeChTNEROvÁ, Životopisný slovník pražské univerzity. Filozofická a teologická fakulta 1654-1773, Praha 1986, s. 381.

25 Biographisches Lexikon des Kaiserthums Oesterreich, XXVIII, Wien 1874, s. 72.

26 Čeněk ZíBrt, Bibliografie české historie, I, Praha 1900. č. 973, s. 54. Pod č. 998, s. 55 je uvedena tato rozprava znovu, tentokrát se Steplingovým autorstvím, ale ve zcela konfusní formě, kde došlo k propletení názvů dvou různých publikací.

27 Stanistav WydRA, Vita admodum reverendi ac magnifici viri Josephi Stepling..., Pragae 1779, s. 59, nebo František Martin PELzel, Abbildungen böhmischer und mährischer Gelehrten und Künstler, nebst kurzen Nachrichten von ihren Leben und Werken, IV, Prag 1782, s. 171.

28 Srov. např. Josef DoBrovský, Litterarisches Magazin für Böhmen und Mähren, I, Prag 1786, s. 153-154; Cassian HallaschKa, Versuch einer geschichtlichen Darstellung dessen, was an der Karl-Ferdinandischen 
Tato rozprava o zemětřesení musela vzniknout hodně rychle, když už 30. března 1756 o ní mohlo shromáždění pedagogů filosofické fakulty debatovat. ${ }^{29}$ Její autor se domnívá, že zemětřesení vyvolává bud' gravitační, nebo elastická síla. Obě působí uvnitř země, jež je plna nejrůznějších prohlubní. Tuto elastickou sílu vytváří nejjemnější fluidum, jež záleží hlavně ve vodní páře, minerálních fluidech a v podzemním ohni. Fluidum bylo pro autory 18. století naprosto univerzálním prostředkem, který „nasazovali“ všude tam, kde si s vysvětlením podstaty jevu nevěděli rady - a takových př́padů bylo velmi mnoho. Byl to samozřejmě přístup spekulativní, při daném stupni tehdejších znalostí o zemské kůře jiný ale ani být nemohl. Autor pak připomíná několik větších zemětřesení posledních desetiletí, ale pokusit se vysvětlit blíže zemětřesení lisabonské se neodvažuje.

Rozborem dalších Steplingových děl jsme došli k názoru, že autorem této rozpravy je nejpravděpodobněji, jak uvádí starší literatura, přece jen Stepling. Níže (viz pozn. 38) jsme podpořili tento názor citátem z jeho textu z r. 1763, kde znovu mluví o fluidu nadaném obrovskou elastickou silou. Máme však pro tento názor i další argument, a to ze Steplingovy korespondence. V roce jeho smrti, v r. 1778, se na něj obrátil jinak neznámý Franciscus Oesterreicher, který se podepsal jako ,arcibiskupský misionáŕ‘‘: zaslal Steplingovi zprávu o mimořádném úkazu ${ }^{30}$ pozorovaném 9 . března téhož roku u Berouna. Jednalo se o plamen, který šlehal na dvou místech z vrchu Pohled. ${ }^{31}$ Když se k němu přiblížili dva místní obyvatelé asi na 150 kroků, dosud klidný vzduch se silně rozbouřil. Když se vše utišilo, našla se jen jáma s několika kousky železa. Uvnitř vrchu se prý za časů knížete Neklana vykopalo mnoho zlata.

Stepling píše ve své odpovědi z 20. března, ${ }^{32}$ že podobným zprávám př́liš nedůvěřuje, přesto však na dotaz podrobně odpovídá. Myslí si, že to hořely sirné výpary, které mohly z hory unikat, když se z ní předtím těžilo zlato. Když se podzemní výpary - spiritus zahřály, roztáhnuly se, unikly na povrch a způsobily vichr. Č́st této elastické hmoty mohla vymrštit na povrch země i kus skály. Musel být přitom slyšet i podzemní rachot. Na závěr dělá Stepling zajímavou poznámku: nebylo prý nutné obávat se zemětřesení, k těm dochází jen přri mořském pobřeží, při velkých bažinách nebo řekách, výše položeným Čechám nehrozí. Zajímavé přitom je, že zaslaná zpráva o zemětřesení nemluví, ani zdaleka je nepřipomíná. Stepling je však musel mít zafixováno stále kdesi v podvědomí - a jakmile promluvil o své elastické síle, musel se o něm zmínit a znovu uplatnit svou spekulativní teorii.

Tím jsme však předběhli časový sled událostí, vrat'me se do doby, kdy byl vydán autorsky sporný Discursus. Několik let po něm se Stepling k tématu změn teplického pramene pod vlivem lisabonského zemětresení vrátil znovu - v r. 1763 vydává spisek Meditatio de causa mutationis thermarum Teplizensium, factae 1. Nobembris anno 1755, a to spolu

Universität zu Prag in der Experimentalphysik gearbeitet wurde..., Prag 1818, s. 40; nebo Moritz CANTOR, in: Allgemeine Deutsche Biographie, XXX, Leipzig 1890, s. 173.

29 Tato zasedání zavedená na pokyn císařského dvora zvaná consessus nebo conventus philosophici či litterarii měla být jedním z nástrojů při reformě universit, učitelé filosofických fakult se v nich měli seznamovat s aktuálními vědeckými výsledky. V Praze je jako direktor filosofického studia zavedl a řídil Stepling. Blíže o nich Josef Haubelt, Filosofické konsesy Josefa Steplinga, Dějiny věd a techniky 15, 1982, s. 207-221.

30 Relatio phaenomeni ad Beraunam Bohemiae civitatem 9. Martii 1778 dicta, in: Litterarum commercium, s. 627 an.

31 Pohled je pomístní název, který se nám ani s pomocí letopisecké komise berounského městského úřadu bohužel nepodařilo lokalizovat.

32 Tamtéž, s. 629-632. 
s tezemi z univerzální filosofie a s oznámením, že je obhájil a bude promován jakýsi jinak neznámý kandidát Josef Hoffmann z Jilemnice. Spisek měl zvláštní osud: ačkoli jej ve svých bibliografiích citují Vydra, Pelcl a dokonce i Zíbrt, ${ }^{33}$ není dnes v žádné z našich knihoven k dohledání. Seznámili jsme se až s jeho přetiskem, který uveřejnil dlouho po Steplingově smrti teplický lékař John. ${ }^{34}$ Vedle toho jej jako př́lohu svého článku otiskl i J. Polišenský. 35

Z textu tohoto drobného spisku o několika stranách je patrné, že se Stepling o mimořádný teplický jev i nadále hluboce zajímal. Opatřil si k němu i další literaturu, která se začala po celé Evropě doslova rojit. Orientoval se jen na literaturu německou, uvádí z ní čtyři spisy: Allgemeine Geschichte der Erdbeben od J. Fr. Seyfarta (Frankfurt u. Leipzig 1756), dvoudílný spis Lissabon, wie es ohnlängst noch im schönsten Flor gestanden, am 1. Novembr. des 1755sten Jahres aber durch ein entsetzliches Erdbeben in einen Stein-Hauffen verwandelt worden podepsaný jen iniciálami M. G. H. (Stolpen 1756), Angestellte Betrachtung über die den 1. November 1755 so ausserordentliche Erdbeben und Meeresbewegungen aufgesetzt, jehož autorem je J. A. E. Maschenbauer (Augsburg 1756) a spis teplického lékaře Troschela, který jsme výše již několikrát citovali. ${ }^{36} \mathrm{Z}$ jiných souvislostí však víme, že měl i knihu J. G. Krügera vydanou v r. 1756 (viz pozn. 15).

Na počátku svého textu Stepling znovu resumuje události z 1. listopadu 1755, ve srovnání s jeho prvotní reakcí to ale činí značně informovaněji a vyspěleji. Uvažuje už o zemětřesení ve velikých kontinentálních dimensích: na jedné straně se zmiňuje o jeho důsledcích v marockém Tangeru, na druhé straně uvádí, že do Švédska nedorazilo, jen na dvou norských jezerech prý došlo k hlasité turbulenci. ${ }^{37}$ Rozlišuje také mezi prŕpady, kde došlo ke skutečnému pohybu země a kde se jednalo jen o druhotně vyvolané jevy. Tuto část pak uzavírá tím, že příčinou zemětřesení je jemné fluidum nadané obrovskou elastickou silou. ${ }^{38}$ Ohnisko, kde lisabonské zemětřesení vzniklo, bylo hluboko pod oceánem, jeho elastická síla prý roztrhala skály, které ji svíraly, začala vnikat do dalších zemských prohlubní a nabírat na síle. Díky ní se urychlilo i proudění podzemních vod, jež způsobilo změny na teplických pramenech. Stepling se pokoušel rovněž o vysvětlení zvýšené teploty vod, přiznal si však, že uspokojivě nevysvětlil, proč voda přestala a znovu začala tryskat.

V této chvíli došlo k ojedinělému momentu. Stepling zde opustil latinu a dokončil svůj text v němčině. Poreferoval o literatuře, o níž jsme se již zmínili, a vyslovil se pak k průběhu události v Teplicích. Měl možnost mluvit s očitým svědkem: není prý pravda, že by

33 Srov. Č. ZíBrt, Bibliografie české historie, I., č. 997, s. 55.

34 Johann Dionys John, Die Bäder zu Tepliz in Böhmen, in einer kurzen physisch-medizinischen und politischen Uebersicht, Dresden 1792, s. 64-70.

35 Josef PolišEnský, A Boémia e o terramoto de Lisboa de 1755, Ibero-americana Pragensia, A Anuario del Centro de Estudios Ibero-americanos de la Universidad Carolina de Praga, 31, 1997, s. 219-225, zde s. 223-225. Renomovaný historik $\mathrm{k}$ této př́lloze nepřipojil ani jediné slůvko vysvětlení či komentáře, navíc se ani neobtěžoval, aby uvedl, odkud text přetiskl.

36 Je tak trochu s podivem, že ani jeden z výše uvedených svazků není v dnešním fondu klementinské Národní knihovny. Její předchůdce totiž po Steplingově smrti jeho knihovnu převzal.

37 Stepling se přitom dopouští několika nepřesností, když např. Mequinenzu ležící na španělské řece Ebro umist’uje na africké pobřeží, to však nic neubírá na obrovské šíři jeho záběru.

$38, \ldots$ spiritum seu fluidum subtile elasticitate insigni praeditum causam terrae motus statuo.“ J. STEPLING, Meditatio de causa, s. 224 (citováno dle př́lohy J. Polišenského). Slova o elasticitě nápadně připomínají to, co uvádí výše zmíněný spisek Discursus de terrae motus (srov. pozn. 23) a naznačují, že jeho autorem byl asi skutečně Stepling. 
voda vystoupila tak vysoko, aby se po ulicích dalo jezdit lod'kami. Byla na ulicích asi čtvrt hodiny a pak odtekla rourami do kanálu, jednu z nich poškodila. Stepling také pochybuje o tom, že teplota pramene mohla stoupnout o tři stupně. Svou úvahu končí slovy, že na ulici byl i městský úředník, který kolemstojícím řekl: „Lidé, pojd’me se modlit, někde blizko nebo hodně daleko je zemětřeseni." Přri své hluboké víře tím chtěl Stepling jistě připomenout existenci boží, mimoděk tak ale vydal i svědectví o prozíravosti a znalostech - možná i nahodilých - tohoto úředníka.

Teplické téma pak provázelo Steplinga doslova až za hrob. Šest let po jeho smrti vyšel v šestém svazku Pojednání Soukromé společnosti, jímž jejich vydávání skončilo, jeho německý př́ispěvek nazvaný Otázky o zemětřeseni ${ }^{39} \mathrm{Z}$ dlouhého titulu vyrozumíváme, že jde o otázky, které Stepling předložil 29. ledna 1757 filosofickému shromáždění, tedy o text starý více než čtvrt století. Vydavateli Pojednání jej dal zřejmě k disposici St. Vydra, který měl v držení Steplingovu literární pozůstalost. Výše jsme se zmínili o tom, že shromáždění pedagogů pražské filosofické fakulty se zabývalo problematikou zemětřesení již 30. března 1756 (srov. pozn. 23), ted' se ale dozvídáme, že o necelý rok později, 29. ledna 1757, je dal Stepling na pořad jednání znovu. To svědčí o tom, jak hluboce jej problematika zemětřesení zasáhla. V tomto př́íspěvku klade devět otázek o zemětřesení - ty už nejsou bezprostředně spojeny s lisabonskou tragédií z r. 1755, ale mají obecnější charakter. Zároveň na ně Stepling poměrně podrobně odpovídá. Pro nás je to důkazem, jak velkou váhu Stepling těmto filosofickým shromážděním přikládal a jak se na ně pečlivě připravoval.

Nejobšírnější je Steplingův výklad k první otázce, která zkoumá, zda je příčinou zemětřesení elektrická síla. Analogická situace nastala v dějinách fysiky několikrát: jakmile se objeví nějaký nový jev - a tím elektřina v té době byla - objeví se i tendence použít jej k vysvětlení jiných, dosud méně známých čí neobjasněných př́rodních jevư. Stepling věděl, že elektřinu jako příčinu zemětřesení dal v r. 1750 na pořad dne anglický fysiolog Stephen Hales (1677-1761), po něm benediktinský mnich z italského Monte Cassina Andreas Bina $^{40}$ a zejména profesor helmstedské university Johann Gottlob Krüger (1715-1759). Ten vycházel z představy, že zemětřesení je svým způsobem podzemní bouří - a o elektrické podstatě bouřky se v polovině 50 . let již bezpečně vědělo. Tuto analogii se zdála potvrzovat i obrovská rychlost, jíž se zemětřesení - podobně jako elektřina - šíruilo. Po obšírném výkladu, z něhož je patrné, jak dobře tehdejší znalosti o elektřině Stepling ovládal, tuto představu rázně odmítl a poukázal na „svou“ elastickou sílu. ${ }^{41}$

Pomocí elastické síly, která je v klidovém stavu uzavřena v podzemních proláklinách a ničivě působí, jen když se z nich uvolní, vysvětluje Stepling i další otázky: proč vznikají zemětřesení zejména při mořských pobřežích, proč je provází pěnění vody a akustické efekty, čím se zemětřesení od sebe odlišují, proč probíhají v jakýchsi vlnách, kdy slábnou a znovu zase sílí a zda se na zrrícení budov podílí i gravitační síla.

39 Fragen über das Erdbeben, welche der philosophischen Versammlung im Jahre 1757 den 29 Jänner vorgelegt worden, in: Abhandlungen einer Privatgesellschaft in Böhmen, zur Aufnahme der Mathematik, der vaterländischen Geschichte, und der Naturgeschichte, 6, 1784, s. 218-240.

40 Jeho vysvětlení otiskl Hamburgisches Magazin oder gesammelte Schriften zum Unterricht und Vergnügen..., 10/3, 1752, s. 292-299.

41 „... wir haben schon bey einer anderen Gelegenheit ... gezeiget, dass die elastische Kraft den Erdboden könne überwerfen, und wirklich überworfen habe.“ J. STEPLing, Fragen über das Erdbeben, s. 225. Touto příležitostí musel být výše uvedený Discursus z r. 1756, jehož autorem byl podle našeho názoru právě Stepling. 
V osmé otázce se Stepling znovu vrací k teplické události a obšírně líčí a vysvětluje vše, co se o ní dozvěděl. Na závěr klade otázku, co lze říci pravděpodobného o podstatě a povaze elastické síly. Není toho mnoho: může prý působit hlavně tam, kde je v půdě hodně železa, vitriolové kyseliny a síry. Úplně nakonec si Stepling přece jen znovu položí otázku elektřiny. Dobře ví, že zemětřesení řada elektrických jevů provází, považuje je ale nikoli za př́činu, ale za jeho následek. ${ }^{42}$

$\mathrm{Z}$ veškerého materiálu, který se nám podařilo $\mathrm{k}$ tomuto tématu shromáždit, je patrné, že lisabonské zemětřesení a jeho teplické dozvuky Steplinga hluboce zaujaly. Zmocnil se tohoto tématu způsobem vlastním vědci jeho důslednosti a mnohostranných zájmů. Snažil se o něm získat co nejvíce informací a předestřít je i co nejširšímu okruhu. Neváhal proto využít svého předchozího kontaktu na Jamese Shorta a napsat o Teplicích sdělení nejvýznamnější vědecké instituci té doby. Dopisoval si o něm i se svými dalšími zahraničními korespondenty. Okamžitě dal celý problém - dokonce dvakrát - i na pořad klementinských filosofických shromáždění a začal do něj zasvěcovat i své ŕádové bratry a pedagogy. Pro širší veřejnost vydal i dva spisky - druhý z nich dokonce osm let po celé události, tak dlouho a tak úporně se tímto tématem zabýval. Třetí pak byl otištěn až po jeho smrti.

Jinou záležitostí je, že úkol, který si předsevzal - dobrat se příčin, které zemětřesení vyvolávají -, ležel daleko za hranicemi možností tehdejší vědy. Ani vědec Steplingova formátu nebyl schopen se ho úspěšně zhostit. ${ }^{43}$

JOSEF SMOLKA

\section{Noch einmal zu Joseph Stepling und der Royal Society}

\section{ZUSAMMENFASSUNG}

Kürzlich konnten wir eine Studie veröffentlichen (Anm. 1), in der wir einen jüngst gefundenen Brief Steplings von 1755 an James Short, E.R.S., analysiert haben. Der Brief war dem Fall von Meteoriten in Südböhmen gewidmet. Bald darauf zeigte es sich, dass es noch einen weiteren Brief Steplings aus dem darauffolgenden Jahr an denselben Adressaten gibt. Auch dieser Brief befasste sich mit einer außerordentlichen Naturerscheinung - mit den am 1. November 1755 eingetretenen Veränderungen der Hauptquelle im Kurort Teplitz in Böhmen. Stepling nimmt an, dass es dazu infolge eines tragischen Erdbebens vom selben Tag in Lissabon gekommen sei. Sein Brief wurde in der Versammlung der Royal Society verlesen und nachfolgend in ihren Philosophical Transactions publiziert.

Der vorliegende Beitrag bringt den vollen Wortlaut des Briefes in seiner originalen lateinischen Fassung sowie in einer tschechischen Übersetzung und bemüht sich um dessen ausführliche Kommentierung. Das Phänomen des Erdbebens, dessen Ausläufer noch in einer Entfernung von etwa 2500 Kilometer wirksam waren, hat auf Stepling einen tiefen Eindruck gemacht. Im Jahre 1756 verfasste er eine Abhandlung über die Ursachen des Erdbebens

42 Poslední slova jeho př́spěvku jsou: „Die Elektricität ... ist mehr als eine Folge dieser Operationen der Natur anzusehen, denn überall äussert sich Elektricität, wo heftige Bewegung in den feinsten Theilchen der Materie statt findet." Tamtéž, s. 240.

43 Pro úplnost dodejme, že lisabonské zemětřesení bylo u nás později připomenuto ještě jednou: v r. 1841 mu věnoval článek časopis Prag, s. 640: Symptome des Erdbebens vom 1. November 1755 in Teplitz. Cituje jej Č. ZiвRT, Bibliografie české historie, I, č. 1001, s. 55. 
(Anm. 23). Sieben Jahre später widmete er dem Erdbeben noch eine Meditatio, in der er noch einmal auf alle Hauptfragen dieses Problems zurückkam. Im Jahre 1784 wurden aus seinem Nachlass schließlich seine „Fragen über das Erdbeben“" veröffentlicht, die er 1757 der Versammlung der philosophischen Fakultät vorgelegt hatte.

Bei dem damaligen Kenntnisstand war niemand - auch nicht Stepling - in der Lage, die mit Erdbeben verbundenen komplizierten Fragen zu beantworten. Und so blieb er bei einer spekulativen Hypothese von einem feinsten Fluidum, das, ausgestattet mit einer riesigen elastischen Kraft, die unterirdischen Prozesse beeinflusst und Erdbeben auslöst.

RNDr. Josef Smolka, CSc.

Deutsche Übersetzung Verfasser, sprachliche Revision Wolf B. Oerter

Historický ústav AV ČR, emeritni pracovnik

josef.smolka@gmail.com 


\section{Obrazová př́loha}

218

\section{Soreph Steplings}

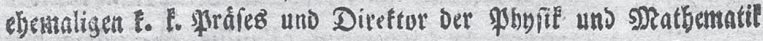
an Der boben Sajule zil \$rag

$$
\begin{aligned}
& \text { f } \mathfrak{i} \text { a } \mathfrak{u} \in \mathbb{i}
\end{aligned}
$$

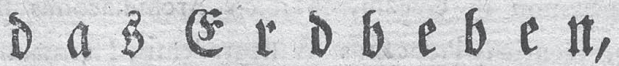

wrldye bet pfitlofophilichen Detfanumlung in Jafgre 1757 ben 29 Jånner vorgelegt roorden.

\section{Erite Frage.}

DE Das Crobeben von einer eleftrifhen Sraft gezel. get nerde?

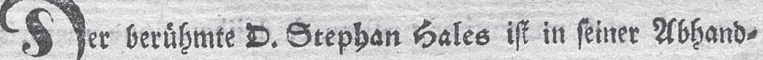
lung liber bas Erobeben, Die ex ben 5+ STpril 1750

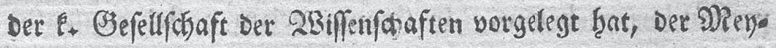
ming, baf́ der Sobalf, ber bas Eonbmet Erbbeben in ebente Demfelben Jahre im SRonate Mär begleitete, von etner frif.

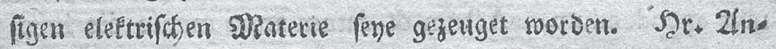
orcas Bins Reltor ber Jhilofophie, uno Jobann Gottlob vers theibigen forfarfinnig, Daßj Die Erfothutterungen ber Erbe, weld)e in Utmbria im Jafire 175 r entitanden, ber eleftriftsen Sitaft zuzufchreiben fene; und Zxüger in feinen Gedanfen von Det Utrache bes Erobebens, Die I756 herausfamen, eignet alle Erfcheinungen, Die im Erobeben bemertet merben, Der elels trifthen Rraft zu. Er gieng zu biefer Mleumung anb ben Stunden libet: neil Das Etdobeben ein gewilles unterirdifches Wete

Obr. 1 Jedna z posledních Steplingových publikací (z 6. sv. Pojednání Soukromé společnosti) - viz pozn. 39 


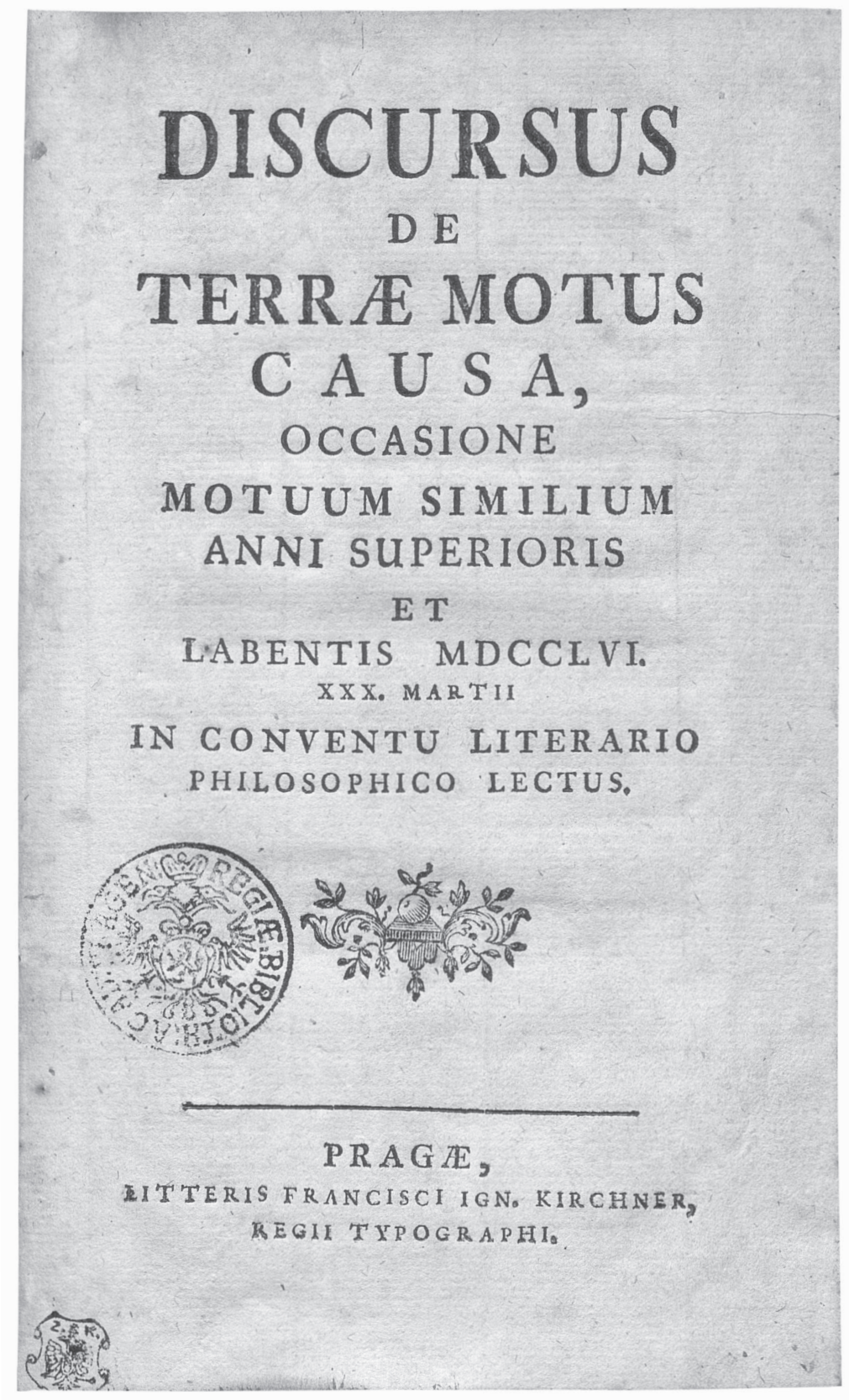

Obr. 2 Titulní list anonymní Rozpravy o př́icině zemětřesení (srov. pozn. 23) 


\section{$\mu$}

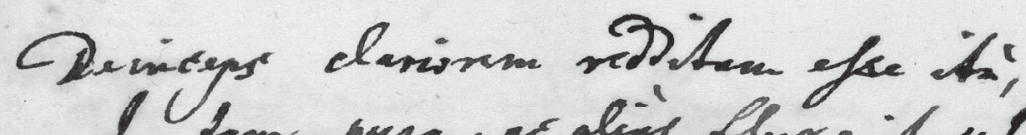

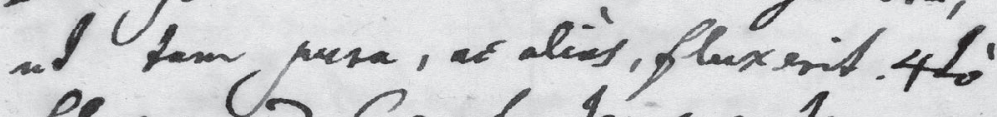

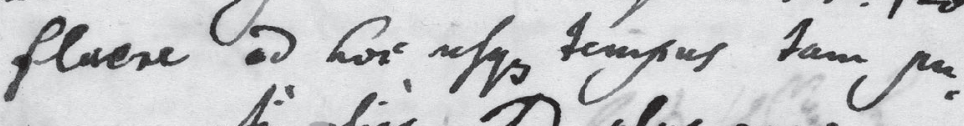

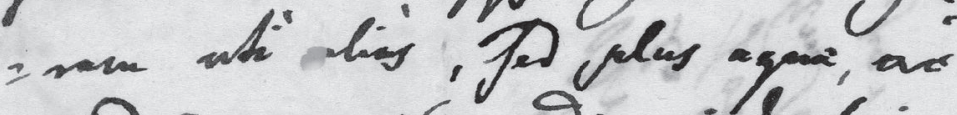
Busingm, vig's metira isterforie froitum Dase Pils Vis Cla.

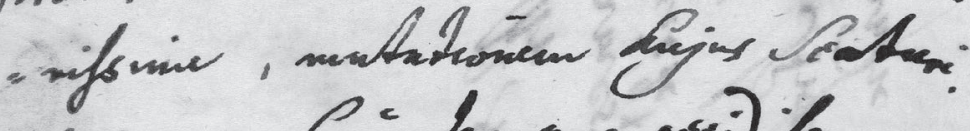

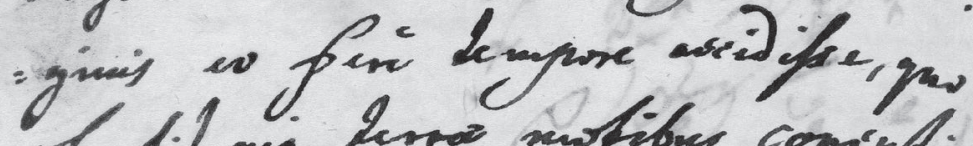

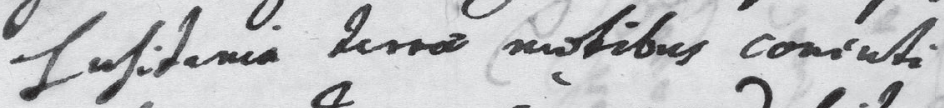
crepte. Inaxe, ciom nom Jubitem.

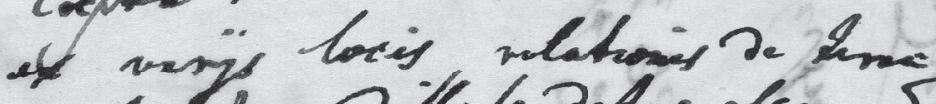
mathe ham Jiffugs ortes fore as

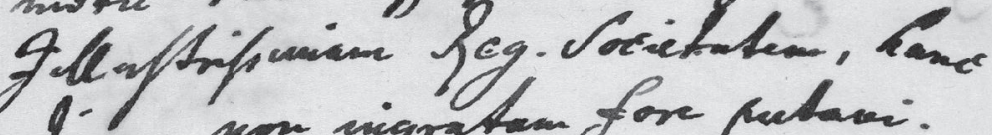
tion non inigratan fore pactavi:

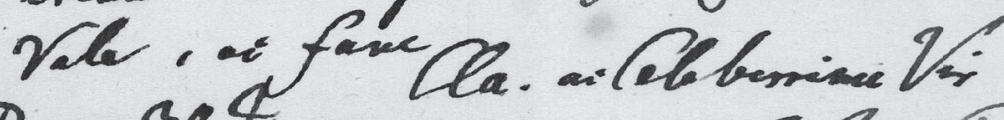

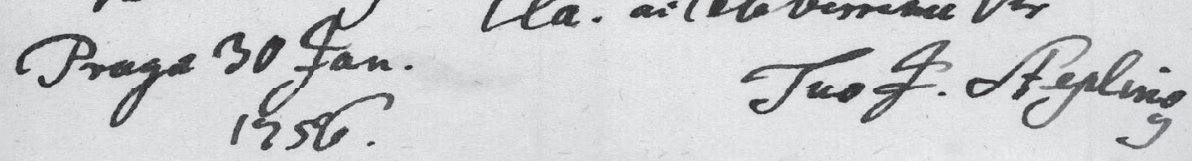

Obr. 3 Závěr Steplingova listu J. Shortovi s jeho vlastnoručním podpisem (viz edice na s. 162) 